Journal of

Psychopharmacology

\title{
Second generation antipsychotics in the treatment of bipolar depression: a systematic review and meta-analysis.
}

\begin{tabular}{|c|c|}
\hline Journal: & Journal of Psychopharmacology \\
\hline Manuscript ID: & JOP-2010-1323 \\
\hline Manuscript Type: & Review \\
\hline $\begin{array}{r}\text { Date Submitted by the } \\
\text { Author: }\end{array}$ & $17-O c t-2010$ \\
\hline Complete List of Authors: & $\begin{array}{l}\text { De Fruyt, Jürgen; AZ Sint-Jan AV, Psychiatry } \\
\text { Deschepper, Ellen; Ghent University, Biostatistics Unit } \\
\text { Audenaert, Kurt; Ghent University, Department of Psychiatry and } \\
\text { Medical Psychology } \\
\text { Constant, Eric; Université Catholique de Louvain, Department of } \\
\text { Psychiatry } \\
\text { Floris, M; Hôpital Notre-Dame, Department of Psychiatry } \\
\text { Pitchot, William; University of Liège, CHU de Liège, Department of } \\
\text { Psychiatry } \\
\text { Sienaert, Pascal; Catholic University Leuven, University Psychiatric } \\
\text { Centre, campus Kortenberg } \\
\text { Souery, Daniel; Psy Pluriel - European Center of Psychological } \\
\text { Medicine, Psy Pluriel - European Center of Psychological Medicine } \\
\text { Claes, Stephan; Catholic University Leuven, University Psychiatric } \\
\text { Centre, campus Gasthuisberg }\end{array}$ \\
\hline \multirow[t]{2}{*}{$\begin{array}{r}\text { Please list at least } 3 \\
\text { keywords which relate to } \\
\text { your manuscript: }\end{array}$} & $\begin{array}{l}\text { second generation antipsychotics, depressive episode, bipolar } \\
\text { disorder, placebo, meta-analysis }\end{array}$ \\
\hline & $\begin{array}{l}\text { Depressive symptoms and episodes dominate the course of bipolar } \\
\text { disorder. However, the therapeutic armamentarium for bipolar } \\
\text { depression is limited. Recent evidence points at the efficacy of } \\
\text { second generation antipsychotics (SGAs) for the treatment of } \\
\text { bipolar depression. } \\
\text { We conducted a systematic review and meta-analysis of the } \\
\text { efficacy and safety of SGAs (randomized, double-blind, placebo- } \\
\text { controlled trials; used in monotherapy) in the treatment of adult } \\
\text { patients with bipolar depression. Publication bias was corrected for } \\
\text { by performing similar searches using the clinical trials register of } \\
\text { the respective pharmaceutical companies, the Cochrane database } \\
\text { and ClinicalTrials.gov. Seven published papers were identified on } \\
\text { the use of aripiprazole, olanzapine and quetiapine. } \\
\text { Internal validity of the trials was fairly good, external validity only } \\
\text { moderate. Different outcome measures of efficacy and safety were }\end{array}$ \\
\hline
\end{tabular}


assessed. When the individual trials were looked at, quetiapine and to a lesser extent olanzapine demonstrated significant improvement in MADRS total scores. This was not demonstrated for aripiprazole. Efficacy was hampered by adverse events, such as weight gain, akathisia, somnolence/sedation.

Both clinical heterogeneity of the included trials and statistical heterogeneity of the meta-analytic data were considerable. The number of quetiapine trials was disproportionate versus the number of trials of aripiprazole and olanzapine. Further research is needed to assess differential efficacy of the different SGAs and their use in clinical practice.

\section{SCHOLARONE ${ }^{\text {m }}$ Manuscripts}




\section{Second generation antipsychotics in the treatment of bipolar depression: a systematic review and meta-analysis.}

Jürgen De Fruyt ${ }^{1,2}$, Ellen Deschepper ${ }^{3,4}$, Kurt Audenaert ${ }^{4}$, Eric Constant ${ }^{5}$, Michel Floris ${ }^{6}$, William Pitchot $^{7}$, Pascal Sienaert ${ }^{8}$, Daniel Souery ${ }^{9,10}$, Stephan Claes ${ }^{2}$

1. Department of Psychiatry, AZ Sint-Jan Brugge-Oostende AV , Brugge, Belgium

2. University Psychiatric Center - Catholic University Leuven, campus Leuven, Belgium

3. Department of Applied Mathematics, Biometrics and Process Control, Ghent University, Gent, Belgium Biostatistics Unit, Ghent University, Gent, Belgium

4. Department of Psychiatry and Medical Psychology, Ghent University, Gent, Belgium

5. Department of Psychiatry, Université Catholique de Louvain, Belgium

6. Department of Psychiatry, Hôpital Notre-Dame, Tournai, Belgium

7. Department of Psychiatry, University of Liège, $\mathrm{CHU}$ of Liège, Liège, Belgium

8. University Psychiatric Center - Catholic University Leuven, campus Kortenberg, Belgium

9. Laboratory of Psychological Medicine, Université Libre de Bruxelles, Brussels, Belgium

10. Psy Pluriel - European Center of Psychological Medicine, Brussels, Belgium 


\section{Disclaimer:}

Funding for this meta-analysis was provided by AstraZeneca Belgium. AstraZeneca Belgium had no role in study design; in the collection, analysis and interpretation of the data; and in the decision to submit the paper for publication.

\section{Corresponding author:}

Jürgen De Fruyt

Department of Psychiatry and Psychosomatics

AZ Sint-Jan Brugge-Oostende AV

Ruddershove 10

8000 Brugge

Belgium

Phone: 003250452394

Fax: 003250453909

E-mail: jurgendefruyt@skynet.be 


\begin{abstract}
Depressive symptoms and episodes dominate the course of bipolar disorder. However, the therapeutic armamentarium for bipolar depression is limited. Recent evidence points at the efficacy of second generation antipsychotics (SGAs) for the treatment of bipolar depression.

We conducted a systematic review and meta-analysis of the efficacy and safety of SGAs (randomized, double-blind, placebo-controlled trials; used in monotherapy) in the treatment of adult patients with bipolar depression. Publication bias was corrected for by performing similar searches using the clinical trials register of the respective pharmaceutical companies, the Cochrane database and ClinicalTrials.gov. Seven published papers were identified on the use of aripiprazole, olanzapine and quetiapine.
\end{abstract}

Internal validity of the trials was fairly good, external validity only moderate. Different outcome measures of efficacy and safety were assessed. When the individual trials were looked at, quetiapine and to a lesser extent olanzapine demonstrated significant improvement in MADRS total scores. This was not demonstrated for aripiprazole. Efficacy was hampered by adverse events, such as weight gain, akathisia, somnolence/sedation.

Both clinical heterogeneity of the included trials and statistical heterogeneity of the meta-analytic data were considerable. The number of quetiapine trials was disproportionate versus the number of trials of aripiprazole and olanzapine. Further research is needed to assess differential efficacy of the different SGAs and their use in clinical practice.

Keywords: second generation antipsychotics, placebo, depressive episode, bipolar disorder, metaanalysis 


\section{Introduction}

Bipolar disorder is a prevalent disorder, with poor symptomatic and psychosocial outcome (De Fruyt \& Demyttenaere, 2007). About half of the time, bipolar patients are symptomatically ill, with pure depressive symptoms predominating over manic, hypomanic or mixed symptoms (Judd et al., 2003; Judd et al., 2002). Some recent trends in the acute treatment of bipolar depression can be identified. Firstly, the importance of adequate mood stabilization is highlighted even in the acute treatment phase (De Fruyt \& Demyttenaere, 2007). Secondly, the use of antidepressants is questioned due to their lack of efficacy, risk of induction of mania and cycle acceleration (Ghaemi et al., 2003; ElMallakh et al., 2007). Thirdly, second generation antipsychotics (SGAs) are being put forward (Calabrese et al., 2005a; Keck, Jr., 2005; Cousins \& Young, 2007). This last trend seems to be in line with their proven efficacy in the acute treatment of mania and recent evidence of their prophylactic efficacy (Scherk et al., 2007; Sienaert \& De Fruyt, 2007). This trend is also reflected in current clinical practice guidelines (Yatham et al., 2009).

However, systematic reviews and meta-analyses addressing the efficacy/effectiveness of SGAs in acute bipolar depression are lacking. Two meta-analyses briefly discussed the efficacy and safety/acceptability of olanzapine and quetiapine monotherapy; more recent data on aripiprazole were not included (Derry \& Moore, 2007; Van Lieshout \& MacQueen, 2010). In another metaanalysis (Cruz et al., 2009), aripiprazole data were included but only efficacy data were analyzed. Therefore, the aim of this paper was to compare the efficacy and safety of SGAs versus placebo, when used in monotherapy for the treatment of bipolar depression. 


\begin{abstract}
Methods
Search

We performed a Medline search. We made a selection for Randomized Controlled Trial (RCT) as article type. The titles and abstracts of articles were searched for: "Bipolar disorder" (MeSH term, search restricted to major topic headings only) AND (depression OR depressive) AND (amisulpride OR aripiprazole $O R$ clozapine $O R$ olanzapine $O R$ paliperidone $O R$ quetiapine $O R$ risperidone $O R$ ziprasidone OR zotepine). In addition, we hand searched the references of retrieved papers and key reviews. We identified the corresponding clinical study summaries of the finally selected papers at the clinical trials register of the respective pharmaceutical companies.
\end{abstract}

For the selected SGAs (for which RCTs were found in the initial Medline search), we performed a similar search using the Cochrane Central Register of Controlled Trials (CENTRAL) database and ClinicalTrials.gov (http://clinicaltrials.gov). The clinical trials register of the respective pharmaceutical companies were finally checked to further identify trials that were not (yet) published.

Selection

In order to be included, trials had to be randomized, double-blind, placebo-controlled, and use a SGA in monotherapy to treat adult patients with documented bipolar disorder and a current depressive episode. Only papers with primary data analysis were withheld. Title and/or abstracts of selected papers were read, potentially useful reports were retrieved in full copy for final selection. Decisions on inclusion or exclusion were made by consensus.

Validity assessment 
Two of the authors (ED \& JDF) independently assessed the quality of the finally selected randomized controlled trials (RCTs) using the method described by Jadad et al. (Jadad et al., 1996): assessment of randomization, double blinding and description of withdrawals/dropouts, yielding a minimum score of 0 points and a maximum score of 5 points.

\section{Data abstraction}

Two of the authors (ED \& JDF) independently extracted the data from the trials. Any disagreement was discussed and decisions were documented. The primary source of data were the published papers of the finally selected RCTs. When data were missing or RCTs were not published yet, the clinical study summaries were used.

\section{Quantitative data synthesis}

The primary outcome of interest was the mean change in Montgomery-Åsberg Depression Rating Scale (Montgomery \& Asberg, 1979) (MADRS) score from baseline to endpoint. Secondary outcome measures were rates of response, remission, and dropout (due to any cause, lack of efficacy, adverse events), treatment emergent mania, mean weight gain, clinically significant weight gain, somnolence/sedation/fatigue, akathisia and extrapyramidal symptoms (EPS).

Efficacy and safety outcomes were combined. For continuous data, a weighted mean difference (WMD) was used as overall measure of treatment effect: this allows for direct interpretation by readers in common units used in the analyzed studies. Inverse variance weighting was used for pooling. Therefore, the mean values and standard deviations of the continuous outcomes, and the number of participants were extracted. When standard deviations were not reported, they were 
derived from $\mathrm{p}$ values and confidence intervals, or the mean standard deviations of the other studies were used.

For dichotomous outcome data, the relative risk (RR) was estimated, along with its $95 \%$ confidence interval $(\mathrm{Cl})$. Relative risks, rather than odds ratios, were chosen since they are intuitively better understood by physicians. The RR is normally defined as the risk of an unfavorable event in the intervention group divided by the risk of this event in the control group. Exceptions were made for the response and remission rate, where RR was calculated as the risk of a favorable event in the intervention group divided by the risk of this event in the control group. When treatment was significantly better than control, the number of participants needed to treat (NNT) was reported. NNT is calculated as the reciprocal of the risk difference (RD). Its $95 \% \mathrm{Cl}$ limits are derived as the inverse of the upper and lower limits of the $95 \% \mathrm{Cl}$ of the RD. NNT was rounded up to the next whole number. In case of a negative NNT (i.e. more good events with control than with treatment), the NNT is called the number of participants needed to harm (NNH). NNH was rounded up to the previous whole number.

The DerSimonian-Laird random-effects model was used in all cases, even if heterogeneity was not statistically significant. Random-effects models are, in general, more conservative than fixed-effects models because they take heterogeneity among studies into account. Heterogeneity was determined by a $\chi 2$ test, contrasting the RR of the individual trials with the pooled RR. Because statistical tests of heterogeneity have low power, a significance level of 0.1 was used (Petitti, 2001).

The results for continuous outcome measures are visualized in a forest plot, which shows the confidence interval for each individual study by a horizontal line. The corresponding point estimate is given by a square whose height is inversely proportional to the standard error of the estimate. The statistical analysis was carried out using $R$, free software available at http://www.r-project.org (version 2.8.0). Figures and results for the random-effects (DerSimonian-Laird) meta-analyses were 
produced in R using the rmeta (Thomas Lumley 2008, Version 2.14) and the meta (Guido Schwarzer 2008, Version 0.9-17) library. 


\section{Results}

Trial flow

A first Medline search was performed on August 6, 2008, and yielded 57 papers, seventeen of which reported on the use of a SGA in patients with bipolar depression. One paper (Corya et al., 2006) was an open-label extension study of olanzapine-fluoxetine combination and olanzapine monotherapy. In one paper (Shelton \& Stahl, 2004) patients were randomized to risperidone, paroxetine or risperidone-paroxetine combination, added to a mood stabilizer. In one paper (Nierenberg et al., 2006) patients were randomly assigned to open-label adjunctive treatment with risperidone, lamotrigine or inositol. In one paper (Brown et al., 2006) patients were randomized to olanzapinefluoxetine combination or lamotrigine. Eight papers (Vieta et al., 2007; Tohen et al., 2007; Cookson et al., 2007; Endicott et al., 2007; Hirschfeld et al., 2006; Williamson et al., 2006; Keck, Jr. et al., 2005; Shi et al., 2004) were secondary analyses. No additional papers were found when the references of retrieved papers and key reviews were looked at. While preparing this manuscript, Medline searches were regularly updated. A final update was performed on December 16, 2009, and yielded 73 papers. No new RCTs were withheld.

So, only five papers (Thase et al., 2006; Calabrese et al., 2005b; Tohen et al., 2003; Amsterdam \& Shults, 2005; Thase et al., 2008) fulfilled the aforementioned selection criteria. In the paper of Amsterdam \& Shults (Amsterdam \& Shults, 2005) patients were randomized to treatment with fluoxetine, olanzapine, olanzapine-fluoxetine combination or placebo. Only nine patients were allocated to treatment with olanzapine: a small sample size in absolute numbers and relative to the other included trials. Furthermore, this paper reported efficacy in box plot figures, without providing actual numeric data. Therefore, this trial was excluded from the meta-analysis. The clinical study summaries of the four remaining papers were identified at the respective clinical trials registers: aripiprazole trials CN138096 and CN138146 (Thase et al., 2008) (Bristol-Myers Squibb, http://ctr.bms.com/ctd/results.do), olanzapine trial F1D-MC-HGGY (Tohen et al., 2003) (Eli Lilly and 
Company, http://www.lillytrials.com) and quetiapine trials 5077US/0049 (Calabrese et al., 2005b) and D1447C00135 (Thase et al., 2006) (AstraZeneca, http://www.astrazenecaclinicaltrials.com).

In the AstraZeneca clinical trials register three additional trials were found: D1447C00134, D1447C00001 and D144CC00002. While preparing the final version of this manuscript, data of these additional quetiapine trials were published: D1447C00134 (McElroy et al., 2010), D1447C00001 (Young et al., 2010) and D144CC00002 (Suppes et al., 2010).

No further trials were identified for aripiprazole, olanzapine and quetiapine in the respective clinical trials registers, CENTRAL database and ClinicalTrials.gov.

In summary, we finally selected seven published papers, three of which were not published yet at the first phase of our searches and data analysis.

Study characteristics

Five papers (Calabrese et al., 2005b; Thase et al., 2006; Young et al., 2010; McElroy et al., 2010; Suppes et al., 2010) reported on the use of quetiapine. In two of these trials patients were randomized to quetiapine (300 or $600 \mathrm{mg} /$ day) or placebo (Calabrese et al., 2005b; Thase et al., 2006). In one trial (McElroy et al., 2010) patients were randomized to quetiapine (300 or 600 $\mathrm{mg} /$ day), paroxetine or placebo. In one trial (Young et al., 2010) patients were randomized to quetiapine (300 or $600 \mathrm{mg} /$ day), lithium or placebo. In one trial (Suppes et al., 2010) patients were randomized to quetiapine sustained-release ( $300 \mathrm{mg} /$ day) or placebo. This resulted in 5 trial arms of quetiapine $300 \mathrm{mg} /$ day and 4 trial arms of quetiapine $600 \mathrm{mg} /$ day. One paper (Tohen et al., 2003) reported on the use of olanzapine ( 5 to $20 \mathrm{mg} /$ day). One paper (Thase et al., 2008) reported on two trials of aripiprazole ( 5 to $30 \mathrm{mg} /$ day). 
Overall, 2610 patients were randomized to SGAs, 1501 patients to placebo. The mean change in MADRS score from baseline to week 8 was the primary efficacy measure in all studies. Assessments were done weekly in three quetiapine trials (Calabrese et al., 2005b; Thase et al., 2006; Suppes et al., 2010) and the aripiprazole trials (Thase et al., 2008). In two quetiapine trials (Young et al., 2010; McElroy et al., 2010), assessments were performed at baseline, weeks 1 and 2, and then every two weeks until week 8 . In the olanzapine trial no assessments were done on week 5 and 7(Tohen et al., 2003). Clinical and sociodemographic characteristics are summarized in Table 1. A more detailed description of selected patients (mainly based upon inclusion and exclusion criteria) is given in Table 2.

Validity assessment

All trial reports scored 3 points or more when assessed by the method of Jadad et al. (Jadad et al., 1996): adequate reporting of randomization, double blinding and withdrawals/dropouts.

\section{Quantitative data synthesis}

Efficacy/effectiveness and safety data were analyzed for quetiapine, olanzapine and aripiprazole versus placebo, whenever comparable data were available. The authors decided to separate quetiapine 300 and $600 \mathrm{mg}$. This decision was based upon the clinical profile with expected differences in efficacy and safety.

Efficacy/effectiveness 
Figure 1. summarizes the results of the primary efficacy measure (MADRS mean change from baseline to endpoint).

Table 3. summarizes the results of secondary efficacy/effectiveness measures: response, remission, dropout due to lack of efficacy and overall dropout. These dichotomous data are presented as RR and NNT/NNH.

Subtle differences were found in the definition of response and remission. In all but one of the trials response was defined as $\geq 50 \%$ reduction from baseline to endpoint on the MADRS score. In the olanzapine trial (Tohen et al., 2003), response was defined as $\geq 50 \%$ reduction from baseline to endpoint on the MADRS score and completion of at least four weeks of study. In all the quetiapine trials (Calabrese et al., 2005b; Thase et al., 2006; Young et al., 2010; McElroy et al., 2010; Suppes et al., 2010), remission was defined as a MADRS score $\leq 12$ at endpoint. In the olanzapine trial (Tohen et al., 2003), remission was defined as a MADRS score $\leq 12$ at endpoint and completion of at least four weeks of study. In the aripiprazole trials (Thase et al., 2008), remission was defined as a MADRS score $\leq 8$ at endpoint.

In all trials, drop-out due to "lack of efficacy" was described. Additional and overlapping causes of discontinuation were described: "condition under investigation worsened" (Suppes et al., 2010) and "relapsed to depression" (Tohen et al., 2003). Only data on "lack of efficacy" were used for analysis.

Safety

Figure 2. summarizes the results on weight gain.

Table 4. summarizes the results of other safety measures: clinically significant weight gain (defined as $\geq 7 \%$ increase from baseline to endpoint), EPS and akathisia, somnolence/sedation/fatigue, 
treatment emergent mania and dropout due to adverse events. These dichotomous data are presented as RR.

The assessment of EPS and/or akathisia was heterogeneous across the trials. In all quetiapine trials, EPS and akathisia were assessed by the Simpson-Angus Rating Scale (SAS) and the Barnes Akathisia Rating Scale (BARS) (Calabrese et al., 2005b; Thase et al., 2006; Young et al., 2010; McElroy et al., 2010; Suppes et al., 2010). In one trial (McElroy et al., 2010), an additional scale was used: the Abnormal Involuntary Movement Scale (AIMS). However, these quetiapine trials differed in the final reporting of rating scale scores: mean change in SAS from baseline (Calabrese et al., 2005b; Thase et al., 2006; Young et al., 2010), number of patients with an increase in SAS from baseline (Calabrese et al., 2005b; McElroy et al., 2010), mean change in BARS from baseline (Calabrese et al., 2005b; Young et al., 2010; McElroy et al., 2010), mean BARS score at last assessment (Thase et al., 2006), number of patients with an increase from baseline (Thase et al., 2006), number of patients with "no change" or "improvement" in SAS and BARS scores from baseline (Suppes et al., 2010). In all quetiapine trials the standardized assessments were supplemented by a mentioning of adverse events "considered to be EPS" (Calabrese et al., 2005b; Thase et al., 2006) or adverse events "potentially associated with EPS" (Young et al., 2010; McElroy et al., 2010; Suppes et al., 2010). It was not always clear how this was assessed or conceptualized. In the Young et al. (Young et al., 2010) paper, adverse events "potentially associated with EPS" included the Medical Dictionary for Regulatory Activities (MedDRA) terms akathisia, hypokinesia, restlessness, tremor, dyskinesia, extrapyramidal disorder, psychomotor hyperactivity, hyperkinesia, hypertonia, muscle rigidity, and nuchal rigidity. In the McElroy et al. (McElroy et al., 2010) paper, adverse events "potentially associated with EPS" included the MedDRA terms akathisia, restlessness, tremor, dyskinesia, extrapyramidal disorder, dystonia, cogwheel rigidity, dyskinesia, hypokinesia and movement disorder. In the Suppes et al. (Suppes et al., 2010) paper, adverse events "potentially associated with EPS" included the MedDRA terms akathisia, dystonia, extrapyramidal disorder, hypertonia and tremor. In the Calabrese et al. (Calabrese et al., 
2005b) clinical trial report, rates of akathisia were reported, but these rates were not reported in the published paper. In the Thase et al. (Thase et al., 2006) clinical trial report, rates of "extrapyramidal disorder" were reported; these rates differed from the rates of adverse events "considered to be EPS" reported in the published paper.

In the olanzapine trial (Tohen et al., 2003), EPS were assessed by the SAS and the AIMS. In the published paper, it was only reported that "the mean change in and emergence of EPS were low, with no statistical differences across treatment groups". The percentage of patients who used anticholinergic medications at least once during the trial was also mentioned. In the clinical trial report, rates of treatment-emergent parkinsonism and dyskinesia were mentioned. These rates were based on the changes in SAS and AIMS.

In the aripiprazole trials (Thase et al., 2006), EPS were assessed using the SAS, AIMS and BARS. Overall rates of "EPS-related adverse events" were reported, as well as more specific rates of akathisia and "EPS-related adverse events other than akathisia". Also reported were changes from baseline to endpoint in SAS, AIMS and BARS score.

In order to have a homogeneous assessment of EPS, only data for quetiapine (Calabrese et al., 2005b; Thase et al., 2006; Young et al., 2010; McElroy et al., 2010; Suppes et al., 2010) and aripiprazole (Thase et al., 2008) could be used: "adverse events considered to be EPS"/"adverse events potentially associated with EPS" and "EPS-related adverse events" respectively. Likewise, in order to have a homogeneous assessment of akathisia, only limited data for quetiapine (Calabrese et al., 2005b) and aripiprazole (Thase et al., 2008) were used.

In all trials, somnolence/fatigue/asthenia/sedation were assessed. However, not all trials reported on all these different adverse events, nor was it stated how these overlapping adverse events were defined. 
In the quetiapine trials (Calabrese et al., 2005b; Thase et al., 2006; Young et al., 2010; McElroy et al., 2010; Suppes et al., 2010) treatment-emergent mania was defined as a Young Mania Rating Scale score (YMRS) $\geq 16$ on any two consecutive visits or at the final assessment, or an adverse event of mania or hypomania. In the olanzapine trial (Tohen et al., 2003), treatment-emergent mania was defined as a YMRS score of $<15$ at baseline and $\geq 15$ at any time thereafter. Treatment-emergent mania (with also data for mixed episodes) was unclearly defined in the aripiprazole trials (Thase et al., 2008). For aripiprazole combined data were used for mania and mixed episodes. 


\section{Discussion}

This systematic review and meta-analysis studied the efficacy and safety of SGAs, used in monotherapy for the treatment of patients with bipolar depression. This paper adds to previous meta-analyses by the inclusion of new reports on quetiapine and aripiprazole and the extensive assessment of both efficacy and safety. The authors have tried to minimize the problem of publication bias by not limiting the search to published papers (Medline) only; searches were also performed using the clinical trials register of the respective pharmaceutical companies, the Cochrane Central Register of Controlled Trials database and ClinicalTrials.gov.

Seven papers were identified: one paper on the use of aripiprazole (two trials), one paper on the use of olanzapine and 5 papers on the use of quetiapine (five trial arms of quetiapine $300 \mathrm{mg} /$ day, four trial arms of quetiapine $600 \mathrm{mg} /$ day). All these trials were sponsored by the pharmaceutical industry. We could not identify any published reports on the use of amisulpride, clozapine, paliperidone, risperidone, ziprasidone or zotepine. For ziprasidone, two failed trials were found: not (yet) published when finalizing the manuscript. Overall, 4111 patients were included; 2610 patients were randomized to SGAs and 1501 to placebo. The average patient was middle aged, Caucasian, moderately depressed and treated in an outpatient setting.

The absolute number of included trials was limited and the relative number of quetiapine trials versus trials of olanzapine and aripiprazole was disproportionate: a major limitation for meta-analytic purposes. However, the small number of included trials made it possible to have a closer look at different inclusion and exclusion criteria, subtle nuances in the assessment of efficacy and safety. These issues pertain to the external validity of RCTs and the meta-analytic merging of data that weren't a priori produced for this purpose: issues that are often and inevitably overlooked in large scale meta-analyses. 
Internal validity of the included trials was fairly good as all trial reports scored $\geq 3$ points, when assessed by the method of Jadad et al. (Jadad et al., 1996). External validity was only moderate, since information on recruitment procedure, treatment setting, duration of the current depressive episode, previous antidepressant treatment, previous treatment with mood stabilizers was limited to absent.

When the individual trials were looked at, quetiapine (at both $300 \mathrm{mg}$ and $600 \mathrm{mg}$ ) and to a lesser extent olanzapine demonstrated significant improvement in the MADRS total scores from baseline to endpoint: the primary efficacy endpoint. This was not demonstrated for aripiprazole. Similar results were found for response and remission rates. Important side effects were as could be expected from former RCTs and clinical practice: weight gain (olanzapine, to a lesser extent quetiapine), akathisia (aripiprazole), somnolence (olanzapine and quetiapine $300 \& 600 \mathrm{mg}$ ), sedation (quetiapine $300 \&$ $600 \mathrm{mg}$ ), low rates of EPS and fatigue. The results of weight gain should be interpreted with caution considering the short duration of the trials. As with schizophrenia, patients with bipolar disorder treated with SGAs have an increased risk for a metabolic syndrome (Newcomer, 2007; Correll et al., 2008; Fagiolini et al., 2008); weight gain and other metabolic issues should be evaluated on the longer term. For those SGAs with proven efficacy, the NNH for somnolence/sedation were within the same range (or even lower) than the NNT for response and remission: a rather unfavourable risk/benefit ratio. However, interpretation of these findings should be done with caution, as only limited information is given on the persistence and severity of these side effects.

When meta-analyzed, SGAs as a group were significantly better than placebo in four out of five outcome measures of efficacy: WMD, response, remission and dropout due to inefficacy. Adverse events, significantly more associated with SGAs than with placebo, were (clinically significant) weight gain, EPS, akathisia, somnolence, sedation, fatigue and dropout due to adverse events. However, statistical heterogeneity ( $Q$ and corresponding $p$-value) was found for most efficacy and some safety 
measures: MADRS mean change from baseline to endpoint, remission, global dropout, inefficacy dropout, weight gain, clinically significant weight gain and somnolence.

Besides the many different sources of clinical heterogeneity, as discussed below, differences in the studied drugs should be considered as the primary source of heterogeneity. Although SGAs are often considered as a group for meta-analysis (schizophrenia, mania and unipolar depression), SGAs are not alike and represent themselves an important source of heterogeneity (Scherk et al., 2007; Papakostas et al., 2007; Leucht et al., 2009). This seems true when inspecting the forest plots for WMD (MADRS mean change from baseline to endpoint, weight gain) and the RRs (different efficacy and safety measures): e.g. non overlapping $95 \% \mathrm{Cl}$ for quetiapine ( $300 \& 600 \mathrm{mg}$ ) versus aripiprazole in MADRS score mean change from baseline, for (clinically significant) weight gain (olanzapine versus quetiapine $300 \& 600 \mathrm{mg}$ and aripiprazole), global dropout (olanzapine versus aripiprazole). Interpretation of these results regarding differential efficacy and safety should be done with caution as the primary purpose of a meta-analysis still is the pooling and not the dissecting of data. Furthermore, for a better comparison of the different SGAs, more trials with olanzapine and aripiprazole are needed. Duration of the trials was short and the question remains how the differential efficacy/effectiveness (SGAs versus placebo) evolves over time. In a subgroup of bipolar II patients treated with quetiapine, the change in MADRS score from baseline to endpoint was statistically superior to placebo at most assessments, but did not reach statistical significance at final assessment (Calabrese et al., 2005b). Likewise, statistical significance favouring aripiprazole was observed during weeks 1 to 6 (trial 1 ) and weeks 1 to 5 (trial 2) and was only lost during longer treatment (Thase et al., 2008). Another question, that could not be answered due to the nature of the studied trials (SGAs in monotherapy), was the differential efficacy (versus placebo) of SGAs when added to an ongoing treatment with a mood stabilizer. For antidepressants this differential efficacy is limited to absent (Sachs et al., 2007; Nemeroff et al., 2001). 
Direct evidence of clinical heterogeneity is found in the clinical samples (e.g. number of bipolar II patients, number of patients with a rapid cycling course), the large variation of baseline mean MADRS score (26.5 to 32.6), number of patient contacts. Bipolar II patients were only included in the quetiapine trials. One trial on quetiapine found a lower efficacy in bipolar II than in bipolar I patients(Calabrese et al., 2005b). The advantage of antidepressant agents over placebo is higher in more severely depressed patients, as has been shown for antidepressants (Kirsch et al., 2008) and lamotrigine (Geddes et al., 2009). A higher number of patient contacts is associated with a higher therapeutic impact (Posternak \& Zimmerman, 2007). Thereby, most of these differences are a potential source of heterogeneity.

Heterogeneity is also found in the only partially overlapping definitions of efficacy/effectiveness and safety measures. This latter source of heterogeneity is avoidable and thereby a missed opportunity. Researchers should strive for a better consensus of the definition, use and reporting of outcome measures.

Indirect evidence of heterogeneity is found in the large variation of placebo event rate for most efficacy measures: response ( 30 to $56 \%$ ), remission ( 25 to $55 \%$ ), global dropout ( 28 to $62 \%$ ) and inefficacy dropout (5 to $32 \%$ ). These differences are large for an identical placebo condition and could be explained by known (or unknown) clinical or methodological differences. The complexity of heterogeneity is further highlighted when comparing (visual inspection of the forest plot for MADRS mean change from baseline to endpoint; Figure 1) two quetiapine trials (Thase et al., 2006; Calabrese et al., 2005b) with identical study design: differences for efficacy were found to be higher between different studies (for same dose) than between different doses (for same study). 


\section{Conclusion}

This systematic review has found a considerable amount of data regarding the use of SGAs (in monotherapy) in patients with bipolar depression. Efficacy/effectiveness is found for quetiapine and to a lesser extent olanzapine. In a meta-analytic data analysis of this evidence, SGAs proved to have a superior efficacy versus placebo. However, clinical and statistical heterogeneity was high. An antidepressant 'class effect' of SGAs can't be concluded. Side effects may hamper their clinical use: somnolence, sedation, akathisia, weight gain and other metabolic problems. Despite these limitations, SGAs like quetiapine and olanzapine have a place in the treatment of patients with bipolar depression, for whom treatment options are rather limited (until now mainly adequate mood stabilization, antidepressants and electroconvulsive therapy). Issues that certainly warrant further research are the impact of depression severity at baseline, the antidepressant efficacy/effectiveness beyond the acute phase, the efficacy/effectiveness when added to a mood stabilizer and the long term follow-up of side effects. This research and further clinical experience have to make clear which patients are most likely to benefit, which patients have the best risk/benefit ratio. SGAs (in particular quetiapine and olanzapine) have succeeded in their first 'trial' (i.e. RCTs and evidence based psychiatry) and should now be submitted to their second trial (i.e. careful application and evaluation in real life clinical practice) (Healy, 2009). This meta-analysis further highlights the important differences of SGAs: an overarching category of compounds with different mechanisms of action and clinical usefulness.

From a more methodological point of view, this review highlights how clinical trials are designed in an idiosyncratic way: unclear description of included patients, (subtle) differences in inclusion- and exclusion criteria, procedures, assessment of efficacy and safety, ... The external validity of trials is thereby limited and individual trials are still difficult to compare. 


\section{References}

Amsterdam J D, Shults J (2005) Comparison of fluoxetine, olanzapine, and combined fluoxetine plus olanzapine initial therapy of bipolar type I and type II major depression - lack of manic induction. J Affect Disord 87: 121-130

Brown E B, McElroy S L, Keck P E, Jr, Deldar A, Adams D H, Tohen M, Williamson D J (2006) A 7-week, randomized, double-blind trial of olanzapine/fluoxetine combination versus lamotrigine in the treatment of bipolar I depression. J Clin Psychiatry 67: 1025-1033

Calabrese J R, Elhaj O, Gajwani P, Gao K (2005a) Clinical highlights in bipolar depression: focus on atypical antipsychotics. J Clin Psychiatry 66 (Suppl 5): 26-33

Calabrese J R, Keck P E, Jr, Macfadden W, Minkwitz M, Ketter T A, Weisler R H, Cutler A J, McCoy R, Wilson E, Mullen J (2005b) A randomized, double-blind, placebo-controlled trial of quetiapine in the treatment of bipolar I or II depression. Am J Psychiatry 162: 1351-1360

Cookson J, Keck P E, Jr, Ketter T A, Macfadden W (2007) Number needed to treat and time to response/remission for quetiapine monotherapy efficacy in acute bipolar depression: evidence from a large, randomized, placebo-controlled study. Int Clin Psychopharmacol 22: $93-100$

Correll C U, Frederickson A M, Kane J M, Manu P (2008) Equally increased risk for metabolic syndrome in patients with bipolar disorder and schizophrenia treated with secondgeneration antipsychotics. Bipolar Disord 10: 788-797 
Corya S A, Perlis R H, Keck P E, Jr, Lin D Y, Case M G, Williamson D J, Tohen M F (2006) A 24-week open-label extension study of olanzapine-fluoxetine combination and olanzapine monotherapy in the treatment of bipolar depression. J Clin Psychiatry 67: 798-806

Cousins D A \& Young A H (2007) The armamentarium of treatments for bipolar disorder: a review of the literature. Int J Neuropsychopharmacol 10: 411-431

Cruz N, Sanchez-Moreno J, Torres F, Goikolea J M, Valenti M, Vieta E (2009) Efficacy of modern antipsychotics in placebo-controlled trials in bipolar depression: a meta-analysis. Int J Neuropsychopharmacol: 1-10

De Fruyt J, Demyttenaere K (2007) Bipolar (spectrum) disorder and mood stabilization: standing at the crossroads? Psychother Psychosom 76: 77-88

Derry S, Moore R A (2007). Atypical antipsychotics in bipolar disorder: systematic review of randomised trials. BMC Psychiatry 7: 40

El-Mallakh R S, Karippot A, Ghaemi S N (2007) Antidepressants in bipolar depression. In El-Mallakh R S, Ghaemi S N (eds), Bipolar depression. A comprehensive guide. American Psychiatric Publishing, Arlington, VA.

Endicott J, Rajagopalan K, Minkwitz M, Macfadden W (2007) A randomized, double-blind, placebocontrolled study of quetiapine in the treatment of bipolar I and II depression: improvements in quality of life. Int Clin Psychopharmacol 22: 29-37

Fagiolini A, Chengappa K N, Soreca I, \& Chang J (2008) Bipolar disorder and the metabolic syndrome: causal factors, psychiatric outcomes and economic burden. CNS Drugs 22: 655-669 
Geddes J R, Calabrese J R, Goodwin G M (2009) Lamotrigine for treatment of bipolar depression: independent meta-analysis and meta-regression of individual patient data from five randomised trials. Br J Psychiatry 194: 4-9

Ghaemi S N, Hsu D J, Soldani F, Goodwin F K (2003) Antidepressants in bipolar disorder: the case for caution. Bipolar Disord 5: 421-433

Healy D (2009) Trussed in evidence? Ambiguities at the interface between clinical evidence and clinical practice. Transcult Psychiatry 46: 16-37

Hirschfeld R M, Weisler R H, Raines S R, Macfadden W (2006) Quetiapine in the treatment of anxiety in patients with bipolar I or II depression: a secondary analysis from a randomized, doubleblind, placebo-controlled study. J Clin Psychiatry 67: 355-362

Jadad A R, Moore R A, Carroll D, Jenkinson C, Reynolds D J, Gavaghan D J, McQuay D M (1996) Assessing the quality of reports of randomized clinical trials: is blinding necessary? Control Clin Trials 17: 1-12

Judd L L, Akiskal H S, Schettler P J, Coryell W, Endicott J, Maser J D, Solomon D A, Leon A C, Keller M B (2003) A prospective investigation of the natural history of the long-term weekly symptomatic status of bipolar II disorder. Arch Gen Psychiatry 60: 261-269

Judd L L, Akiskal H S, Schettler P J, Endicott J, Maser J, Solomon D A, Leon A C, Rice J A, Keller M B (2002) The long-term natural history of the weekly symptomatic status of bipolar I disorder. Arch Gen Psychiatry 59: 530-537

Keck P E, Jr (2005) Bipolar depression: a new role for atypical antipsychotics? Bipolar Disord 7 (Suppl 4): $34-40$ 
Keck P E, Jr, Corya S A, Altshuler L L, Ketter T A, McElroy S L, Case M, Briggs S D, Tohen M (2005) Analyses of treatment-emergent mania with olanzapine/fluoxetine combination in the treatment of bipolar depression. J Clin Psychiatry 66: 611-616

Kirsch I, Deacon B J, Huedo-Medina T B, Scoboria A, Moore T J, Johnson B T (2008) Initial severity and antidepressant benefits: a meta-analysis of data submitted to the Food and Drug Administration. PLoS Med 5: e45

Leucht S, Corves C, Arbter D, Engel R R, Li C, Davis J M (2009) Second-generation versus firstgeneration antipsychotic drugs for schizophrenia: a meta-analysis. Lancet 373: 31-41

McElroy S L, Weisler R H, Chang W, Olausson B, Paulsson B, Brecher M, Agambaram V, Merideth C, Nordenhem A, Young A H (2010) A double-blind, placebo-controlled study of quetiapine and paroxetine as monotherapy in adults with bipolar depression (EMBOLDEN II). J Clin Psychiatry 71: 163-174

Montgomery S A \& Asberg M (1979) A new depression scale designed to be sensitive to change. $\mathrm{Br}$ J Psychiatry 134: 382-389

Nemeroff C B, Evans D L, Gyulai L, Sachs G S, Bowden C L, Gergel I P, Oakes R, Pitts C D (2001) Doubleblind, placebo-controlled comparison of imipramine and paroxetine in the treatment of bipolar depression. Am J Psychiatry 158: 906-912

Newcomer J W (2007) Metabolic considerations in the use of antipsychotic medications: a review of recent evidence. J Clin Psychiatry 68 (Suppl 1): 20-27

Nierenberg A A, Ostacher M J, Calabrese J R, Ketter T A, Marangell L B, Miklowitz D J, Miyahara S, Bauer M S, Thase M E, Wisniewski S R, Sachs G S (2006) Treatment-resistant bipolar depression: a STEP-BD equipoise randomized effectiveness trial of antidepressant augmentation with lamotrigine, inositol, or risperidone. Am J Psychiatry 163: 210-216 
Papakostas G I, Shelton R C, Smith J, \& Fava M (2007) Augmentation of antidepressants with atypical antipsychotic medications for treatment-resistant major depressive disorder: a metaanalysis. J Clin Psychiatry 68: 826-831

Petitti D B (2001) Approaches to heterogeneity in meta-analysis. Stat Med 20: 3625-3633

Posternak M A, Zimmerman M (2007) Therapeutic effect of follow-up assessments on antidepressant and placebo response rates in antidepressant efficacy trials: meta-analysis. Br J Psychiatry 190: $287-292$

Sachs G S, Nierenberg A A, Calabrese J R, Marangell L B, Wisniewski S R, Gyulai L, Friedman E S, Bowden C L, Fossey M D, Ostacher M J, Ketter T A, Patel J, Hauser P, Rapport D, Martinez J M, Allen M H, Miklowitz D J, Otto M W, Dennehy E B, Thase M E (2007) Effectiveness of adjunctive antidepressant treatment for bipolar depression. N Engl J Med 356: 1711-1722

Scherk H, Pajonk F G, Leucht S (2007) Second-generation antipsychotic agents in the treatment of acute mania: a systematic review and meta-analysis of randomized controlled trials. Arch Gen Psychiatry 64: 442-455

Shelton R C, Stahl S M (2004) Risperidone and paroxetine given singly and in combination for bipolar depression. J Clin Psychiatry 65: 1715-1719

Shi L, Namjoshi M A, Swindle R, Yu X, Risser R, Baker R W, Tohen M (2004) Effects of olanzapine alone and olanzapine/fluoxetine combination on health-related quality of life in patients with bipolar depression: secondary analyses of a double-blind, placebo-controlled, randomized clinical trial. Clin Ther 26: 125-134

Sienaert P, De Fruyt J (2007) Atypische antipsychotica en terugvalpreventie. In Sienaert P, De Fruyt J (eds), Preventie van bipolaire stoornissen. Wolters Kluwer Belgium NV, Mechelen. 
Suppes T, Datto C, Minkwitz M, Nordenhem A, Walker C, Darko D (2010) Effectiveness of the extended release formulation of quetiapine as monotherapy for the treatment of acute bipolar depression. J Affect Disord 121: 106-115

Thase M E, Jonas A, Khan A, Bowden C L, Wu X, McQuade R D, Carson W H, Marcus R N, Owen R (2008) Aripiprazole monotherapy in nonpsychotic bipolar I depression: results of 2 randomized, placebo-controlled studies. J Clin Psychopharmacol 28: 13-20

Thase M E, Macfadden W, Weisler R H, Chang W, Paulsson B, Khan A, Calabrese J R (2006) Efficacy of quetiapine monotherapy in bipolar I and II depression: a double-blind, placebo-controlled study (the BOLDER II study). J Clin Psychopharmacol 26: 600-609

Tohen M, Calabrese J, Vieta E, Bowden C, Gonzalez-Pinto A, Lin D, Xu W, Corya S (2007) Effect of comorbid anxiety on treatment response in bipolar depression. J Affect Disord 104: 137-146

Tohen M, Vieta E, Calabrese J, Ketter T A, Sachs G, Bowden C, Mitchell P B, Centorrino F, Risser R, Baker R W, Evans A R, Beymer K, Dube S, Tollefson G D, Breier A (2003) Efficacy of olanzapine and olanzapine-fluoxetine combination in the treatment of bipolar I depression. Arch Gen Psychiatry 60: 1079-1088

Van Lieshout R J, MacQueen G M (2010) Efficacy and acceptability of mood stabilisers in the treatment of acute bipolar depression: systematic review. Br J Psychiatry 196: 266-273

Vieta E, Calabrese J R, Goikolea J M, Raines S, Macfadden W (2007) Quetiapine monotherapy in the treatment of patients with bipolar I or II depression and a rapid-cycling disease course: a randomized, double-blind, placebo-controlled study. Bipolar Disord 9: 413-425

Williamson D, Brown E, Perlis R H, Ahl J, Baker R W, Tohen M (2006) Clinical relevance of depressive symptom improvement in bipolar I depressed patients. J Affect Disord 92: 261-266 
Yatham L N, Kennedy S H, Schaffer A, Parikh S V, Beaulieu S, O'Donovan C, MacQueen G, McIntyre R S, Sharma V, Ravindran A, Young LT, Young A H, Alda M, Milev R, Vieta E, Calabrese J R, Berk M, Ha K, Kapczinski F (2009) Canadian Network for Mood and Anxiety Treatments (CANMAT) and International Society for Bipolar Disorders (ISBD) collaborative update of CANMAT guidelines for the management of patients with bipolar disorder: update 2009. Bipolar Disord 11: $225-255$

Young A H, McElroy S L, Bauer M, Philips N, Chang W, Olausson B, Paulsson B, Brecher M (2010) A double-blind, placebo-controlled study of quetiapine and lithium monotherapy in adults in the acute phase of bipolar depression (EMBOLDEN I). J Clin Psychiatry 71: 150-162 


\section{1}

Second generation antipsychotics in the treatment of bipolar depression: a systematic review and meta-analysis.

Jürgen De Fruyt1,2 , Ellen Deschepper3,4, Kurt Audenaert4, Eric Constant5, Michel Floris6, William Pitchot7, Pascal Sienaert8, Daniel Souery9,10, Stephan Claes2

1. Department of Psychiatry, AZ Sint-Jan Brugge-Oostende AV , Brugge, Belgium

2. University Psychiatric Center - Catholic University Leuven, campus Leuven, Belgium

3. Department of Applied Mathematics, Biometrics and Process Control, Ghent University, Gent, Belgium Biostatistics Unit, Ghent University, Gent, Belgium

4. Department of Psychiatry and Medical Psychology, Ghent University, Gent, Belgium

5. Department of Psychiatry, Université Catholique de Louvain, Belgium

6. Department of Psychiatry, Hôpital Notre-Dame, Tournai, Belgium

7. Department of Psychiatry, University of Liège, $\mathrm{CHU}$ of Liège, Liège, Belgium

8. University Psychiatric Center - Catholic University Leuven, campus Kortenberg, Belgium

9. Laboratory of Psychological Medicine, Université Libre de Bruxelles, Brussels, Belgium

10. Psy Pluriel - European Center of Psychological Medicine, Brussels, Belgium

Disclaimer:

Funding for this meta-analysis was provided by AstraZeneca Belgium. AstraZeneca Belgium had no role in study design; in the collection, analysis and interpretation of the data; and in the decision to submit the paper for publication.

Corresponding author:

Jürgen De Fruyt

Department of Psychiatry and Psychosomatics

AZ Sint-Jan Brugge-Oostende AV

Ruddershove 10 
8000 Brugge

Belgium

Phone: 003250452394

Fax: 003250453909

E-mail: jurgendefruyt@skynet.be 
Table 1. Demographic and clinical characteristics (part one)

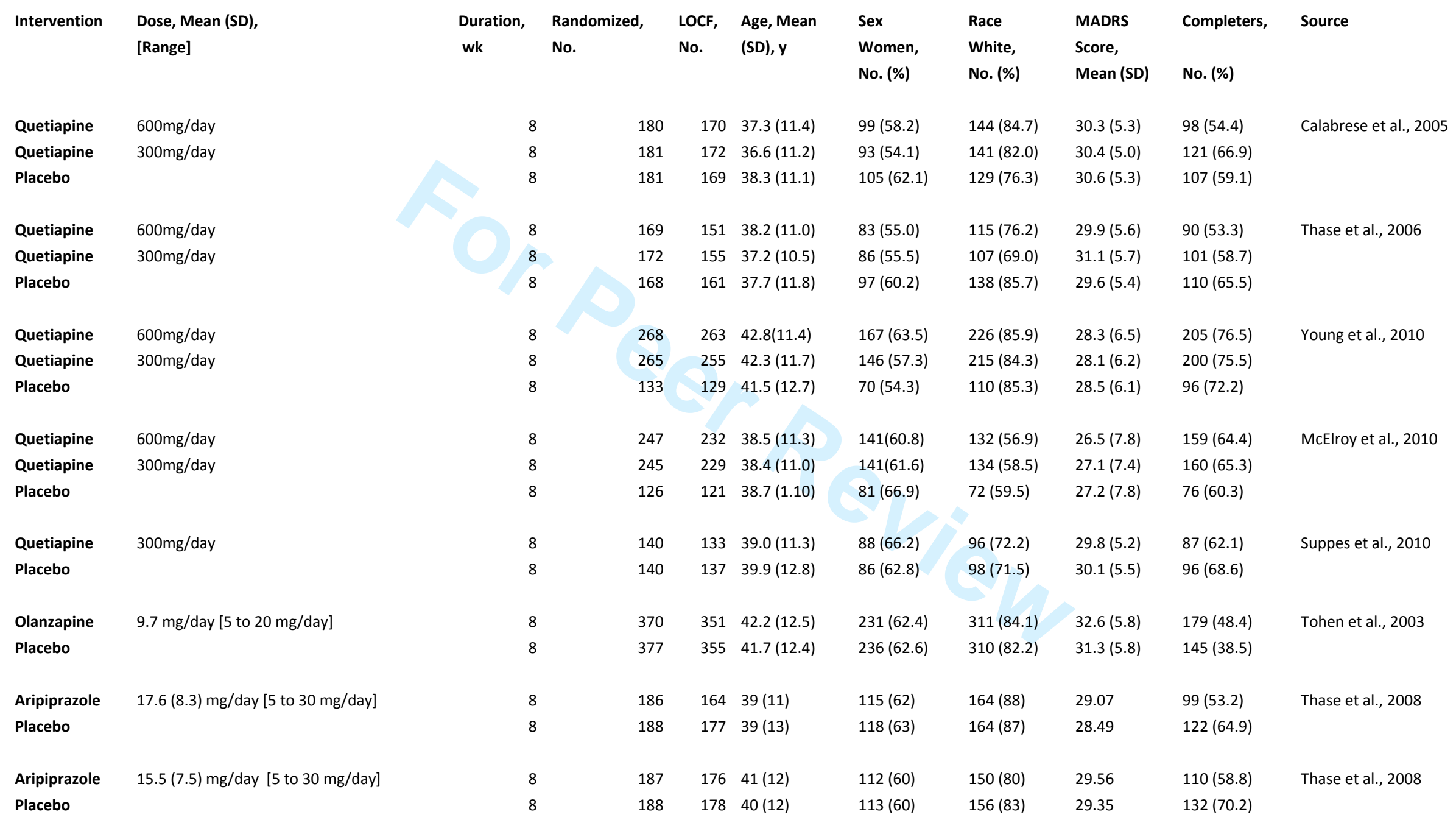


LOCF = last observation carried forward; MADRS = Montgomery-Åsberg Depression Rating Scale 
Table 2. Demographic and clinical characteristics (Part two)

\begin{tabular}{|c|c|c|c|c|c|c|c|}
\hline & Calabrese et al., 2005 & Thase et al., 2006 & McElroy et al., 2010 & Young et al., 2010 & Suppes et al., 2010 & Tohen et al., 2003 & Thase et al, 2008 \\
\hline Age & 18 to 65 years & 18 to 65 years & 18 to 65 years & 18 to 65 years & 18 to 65 years & $\geq 18$ years & 18 to 65 years \\
\hline $\begin{array}{l}\text { Out- versus } \\
\text { inpatient }\end{array}$ & Outpatients & Outpatients & - & Outpatients & Outpatients & $\begin{array}{l}\text { Mainly outpatients } \\
\text { Inpatients: olanzapine } \\
13.8 \% \text {, placebo } 13.3 \%\end{array}$ & Outpatients \\
\hline $\begin{array}{l}\text { Bipolar } \\
\text { subtype }\end{array}$ & $\begin{array}{l}\text { Bipolar I disorder in } \\
\text { majority of patients } \\
\text { Bipolar II disorder: } \\
\text { Quetiapine } 600 \mathrm{mg} \\
32.9 \% \\
\text { Quetiapine } 300 \mathrm{mg} \\
32.6 \% \\
\text { Placebo: } 33.7 \%\end{array}$ & $\begin{array}{l}\text { Bipolar I disorder in } \\
\text { majority of patients } \\
\text { Bipolar II disorder: } \\
\text { Quetiapine } 600 \mathrm{mg} \\
33.1 \% \\
\text { Quetiapine } 300 \mathrm{mg} \\
32.9 \% \\
\text { Placebo: } 31.7 \%\end{array}$ & $\begin{array}{l}\text { Bipolar I disorder in } \\
\text { majority of patients } \\
\text { Bipolar II disorder: } \\
\text { Quetiapine } 600 \mathrm{mg} \\
35.3 \% \\
\text { Quetiapine } 300 \mathrm{mg} \\
35.4 \% \\
\text { Placebo: } 37.2 \%\end{array}$ & $\begin{array}{l}\text { Bipolar I disorder in } \\
\text { majority of patients } \\
\text { Bipolar II disorder: } \\
\text { Quetiapine } 600 \mathrm{mg} \\
38.4 \% \\
\text { Quetiapine } 300 \mathrm{mg} \\
37.3 \% \\
\text { Placebo: } 39.5 \%\end{array}$ & $\begin{array}{l}\text { Bipolar I disorder in } \\
\text { majority of patients } \\
\text { Bipolar II disorder: } \\
\text { Quetiapine } 300 \mathrm{mg} \\
9.5 \% \\
\text { Placebo: } 19.5 \%\end{array}$ & Bipolar I disorder & Bipolar I disorder \\
\hline $\begin{array}{l}\text { Current } \\
\text { depressive } \\
\text { episode }\end{array}$ & & & & & & & \\
\hline Severity & $\begin{array}{l}\text { HDRS } 17 \text {-item } \geq 20 \\
\text { HDRS item } 1 \geq 2 \\
\text { At both screening and } \\
\text { randomization } \\
\text { No current serious } \\
\text { suicidal or homicidal } \\
\text { risk }\end{array}$ & $\begin{array}{l}\text { HDRS } 17 \text {-item } \geq 20 \\
\text { HDRS item } 1 \geq 2 \\
\text { At both screening and } \\
\text { randomization } \\
\text { No current serious } \\
\text { suicidal or homicidal } \\
\text { risk }\end{array}$ & $\begin{array}{l}\text { No HDRS item } 3 \\
\text { (suicide) } \geq 3\end{array}$ & $\begin{array}{l}\text { HDRS } 17 \text {-item } \geq 20 \\
\text { At both screening and } \\
\text { randomization } \\
\text { No current serious } \\
\text { suicidal or homicidal } \\
\text { risk }\end{array}$ & $\begin{array}{l}\text { HDRS } 17 \text {-item } \geq 20 \\
\text { HDRS item } 1 \geq 2 \\
\text { At both screening and } \\
\text { randomization } \\
\text { No current serious } \\
\text { suicidal or homicidal } \\
\text { risk, no HDRS item } 3 \\
\text { (suicide) } \geq 3 \text {, no } \\
\text { attempted suicide } \\
\text { within in the past } 6 \\
\text { months }\end{array}$ & $\begin{array}{l}\text { No suicidal behaviour } \\
\text { within } 3 \text { months }\end{array}$ & $\begin{array}{l}\text { HDRS } 17 \text {-item } \geq 18 \\
\text { HDRS item } 1 \geq 2 \\
\text { At both screening and } \\
\text { randomization, with a } \\
\leq 25 \% \text { decrease in } \\
\text { HDRS score between } \\
\text { screening and } \\
\text { randomization } \\
\text { No significant risk of } \\
\text { suicide }\end{array}$ \\
\hline $\begin{array}{l}\text { Mixed } \\
\text { features }\end{array}$ & $\begin{array}{l}\text { YMRS } \leq 12 \text { at both } \\
\text { screening and } \\
\text { randomization }\end{array}$ & $\begin{array}{l}\text { YMRS } \leq 12 \text { at both } \\
\text { screening and } \\
\text { randomization }\end{array}$ & $\begin{array}{l}\text { YMRS } \leq 12 \text { at both } \\
\text { screening } \\
\text { and randomization }\end{array}$ & $\begin{array}{l}\text { YMRS } \leq 12 \text { at both } \\
\text { screening and } \\
\text { randomization }\end{array}$ & $\begin{array}{l}\text { YMRS } \leq 12 \text { at both } \\
\text { screening and } \\
\text { randomization }\end{array}$ & $\begin{array}{l}\text { Patients with } \\
\text { worsening of manic } \\
\text { symptoms (YMRS } \geq 15 \\
\text { during weeks } 1 \text { to } 3 \text { ) } \\
\text { were discontinued }\end{array}$ & $\begin{array}{l}\text { YMRS } \leq 12 \\
\text { At both screening and } \\
\text { randomization, with < } \\
\text { 4-point increase } \\
\text { between those visits }\end{array}$ \\
\hline
\end{tabular}




\begin{tabular}{|c|c|c|c|c|c|c|c|}
\hline & $\begin{array}{l}\text { Mean YMRS score } \\
\text { (SD): } \\
\text { Quetiapine 600mg } 4.8 \\
\text { (3.2) } \\
\text { Quetiapine } 300 \mathrm{mg} 4.9 \\
\text { (2.8) } \\
\text { Placebo } 4.9(3.2) \\
\end{array}$ & $\begin{array}{l}\text { Mean YMRS score } \\
\text { (SD): } \\
\text { Quetiapine 600mg } 5.4 \\
\text { (2.79) } \\
\text { Quetiapine } 300 \mathrm{mg} 5.8 \\
\text { (3.30) } \\
\text { Placebo } 5.8(3.00) \\
\end{array}$ & $\begin{array}{l}\text { Mean YMRS score } \\
\text { (SE): } \\
\text { Quetiapine 600mg } 5.9 \\
\text { (0.21) } \\
\text { Quetiapine } 300 \mathrm{mg} 5.5 \\
\text { (0.19) } \\
\text { Placebo } 5.9(0.30) \\
\end{array}$ & $\begin{array}{l}\text { Mean YMRS score } \\
\text { (SE): } \\
\text { Quetiapine 600mg } 3.3 \\
\text { (0.12) } \\
\text { Quetiapine } 300 \mathrm{mg} 3.1 \\
\text { (0.12) } \\
\text { Placebo } 3.3(0.19) \\
\end{array}$ & & $\begin{array}{l}\text { Mean YMRS score } \\
\text { (SD): } \\
\text { Olanzapine } 5.0(4.8) \\
\text { Placebo } 4.8(4.6)\end{array}$ & \\
\hline $\begin{array}{l}\text { Psychotic } \\
\text { features }\end{array}$ & - & - & - & - & - & $\begin{array}{l}\text { Olanzapine } 13.5 \% \\
\text { Placebo } 12.7 \%\end{array}$ & No psychotic features \\
\hline $\begin{array}{l}\text { Melancholic } \\
\text { features }\end{array}$ & - & - & - & - & - & $\begin{array}{l}\text { Olanzapine } 66.5 \% \text {, } \\
\text { Placebo } 67.9 \%\end{array}$ & - \\
\hline $\begin{array}{l}\text { Atypical } \\
\text { features }\end{array}$ & - & - & - & - & - & $\begin{array}{l}\text { Olanzapine } 9.2 \% \\
\text { Placebo } 7.7 \% \\
\end{array}$ & - \\
\hline Duration & $\geq 4$ weeks, $\leq 1$ year & $\geq 4$ weeks, $\leq 1$ year & $\geq 4$ weeks, $\leq 1$ year & $\geq 4$ weeks, $\leq 1$ year & $\begin{array}{l}\geq 4 \text { weeks, } \leq 1 \text { year } \\
\text { Mean (SD) duration } \\
\text { of current depressive } \\
\text { episode: } \\
\text { Quetiapine } 300 \mathrm{mg} \\
19.3(12.8) \text { weeks } \\
\text { Placebo } 18.1 \text { (11.2) } \\
\text { weeks }\end{array}$ & $\begin{array}{l}\text { Median length of } \\
\text { current depressive } \\
\text { episode: } \\
\text { Olanzapine } 63 \text { days } \\
\text { Placebo } 82 \text { days }\end{array}$ & $\geq 2$ weeks, $\leq 2$ years \\
\hline $\begin{array}{l}\text { Treatment } \\
\text { resistance }\end{array}$ & $\begin{array}{l}\text { No history of } \\
\text { treatment } \\
\text { nonresponse (i.e. an } \\
\text { adequate trial of }>2 \\
\text { classes of } \\
\text { antidepressants) }\end{array}$ & $\begin{array}{l}\text { No history of } \\
\text { treatment } \\
\text { nonresponse (i.e. an } \\
\text { adequate trial of }>2 \\
\text { classes of } \\
\text { antidepressants) }\end{array}$ & - & $\begin{array}{l}\text { No history of } \\
\text { treatment } \\
\text { nonresponse (i.e. an } \\
\text { adequate trial of } \geq 2 \\
\text { classes of } \\
\text { antidepressants) }\end{array}$ & $\begin{array}{l}\text { No history of } \\
\text { treatment } \\
\text { nonresponse (i.e. an } \\
\text { adequate trial of }>2 \\
\text { classes of } \\
\text { antidepressants) }\end{array}$ & - & $\begin{array}{l}\text { No history of } \\
\text { treatment } \\
\text { nonresponse (i.e. an } \\
\text { adequate trial of } \geq 2 \\
\text { classes of } \\
\text { antidepressants in } \\
\text { combination with } \\
\text { lithium, valproic acid, } \\
\text { carbamazepine or } \\
\text { oxcarbazepine) }\end{array}$ \\
\hline $\begin{array}{l}\text { Previous } \\
\text { treatment }\end{array}$ & - & - & $\begin{array}{l}\text { No known } \\
\text { nonresponse to } \\
\text { quetiapine or } \\
\text { paroxetine }\end{array}$ & $\begin{array}{l}\text { No known } \\
\text { nonresponse to } \\
\text { quetiapine or lithium }\end{array}$ & - & - & - \\
\hline $\begin{array}{l}\text { Course of } \\
\text { illness }\end{array}$ & & & $\begin{array}{l}\text { Rapid cycling course is } \\
\text { allowed, but no more }\end{array}$ & $\begin{array}{l}\text { Rapid cycling course is } \\
\text { allowed, but no more }\end{array}$ & $\begin{array}{l}\text { Rapid cycling course is } \\
\text { allowed, but no more }\end{array}$ & $\begin{array}{l}\text { A history of } \geq 1 \\
\text { previous manic or }\end{array}$ & $\begin{array}{l}\text { No late onset } \\
\text { depression }\end{array}$ \\
\hline
\end{tabular}




\begin{tabular}{|c|c|c|c|c|c|c|c|}
\hline & $\begin{array}{l}\text { Rapid cycling course: } \\
\text { Quetiapine } 600 \mathrm{mg} \\
18.2 \% \\
\text { Quetiapine } 300 \mathrm{mg} \\
24.4 \% \\
\text { Placebo } 20.7 \%\end{array}$ & $\begin{array}{l}\text { Rapid cycling course: } \\
\text { Quetiapine } 600 \mathrm{mg} \\
30.5 \% \\
\text { Quetiapine } 300 \mathrm{mg} \\
28.4 \% \\
\text { Placebo } 32.9 \% \\
\end{array}$ & $\begin{array}{l} \\
\\
\\
\text { Rapid cycling course: } \\
\text { Quetiapine 600mg } \\
15.1 \% \\
\text { Quetiapine } 300 \mathrm{mg} \\
20.1 \% \\
\text { Placebo } 19.8 \%\end{array}$ & $\begin{array}{l} \\
\\
\\
\text { Rapid cycling course: } \\
\text { Quetiapine 600mg } \\
6.1 \% \\
\text { Quetiapine 300mg } \\
\text { 6.3\% } \\
\text { Placebo } 3.9 \% \\
\end{array}$ & $\begin{array}{l} \\
\text { Rapid cycling course: } \\
\text { Quetiapine 300mg } \\
27.1 \% \\
\text { Placebo } 27.7 \%\end{array}$ & $\begin{array}{l}\text { mixed episode of } \\
\text { sufficient severity to } \\
\text { require treatment } \\
\text { with a mood stabilizer } \\
\text { or an antipsychotic } \\
\text { Manic or mixed } \\
\text { episode in the last } 12 \\
\text { months: } \\
\text { Olanzapine } 83.5 \% \\
\text { Placebo } 77.8 \% \\
\text { Rapid cycling course: } \\
\text { Olanzapine } 38.4 \% \\
\text { Placebo } 35.0 \%\end{array}$ & $\begin{array}{l}\text { Median } \pm \text { SD number } \\
\text { of mood episodes } \\
\text { within past } 12 \\
\text { months: placebo } 2.3 \pm \\
1.0 \text {, aripiprazole } 2.4 \pm \\
1.0\end{array}$ \\
\hline \multirow[t]{2}{*}{ Comorbidity } & $\begin{array}{l}\text { No other axis I } \\
\text { disorder as primary } \\
\text { focus of treatment } \\
\text { within } 6 \text { months }\end{array}$ & $\begin{array}{l}\text { No other axis I } \\
\text { disorder as primary } \\
\text { focus of treatment } \\
\text { within } 6 \text { months }\end{array}$ & $\begin{array}{l}\text { No other axis I } \\
\text { disorder as primary } \\
\text { focus of treatment } \\
\text { within } 6 \text { months }\end{array}$ & $\begin{array}{l}\text { No other axis I } \\
\text { disorder as primary } \\
\text { focus of treatment } \\
\text { within } 6 \text { months }\end{array}$ & $\begin{array}{l}\text { No other axis I } \\
\text { disorder as primary } \\
\text { focus of treatment } \\
\text { within } 6 \text { months }\end{array}$ & - & $\begin{array}{l}\text { No other primary } \\
\text { psychiatric disorder } \\
\text { with a major } \\
\text { depressive episode } \\
\text { No obsessive } \\
\text { compulsive disorder, } \\
\text { bulimia nervosa, } \\
\text { attention deficit } \\
\text { hyperactivity disorder } \\
\text { within } 3 \text { months } \\
\text { No cognitive disorder, } \\
\text { psychotic disorder, } \\
\text { borderline or } \\
\text { antisocial personality } \\
\text { disorder }\end{array}$ \\
\hline & $\begin{array}{l}\text { No substance } \\
\text { dependence or } \\
\text { substance use (except } \\
\text { for nicotine) within } 12 \\
\text { months }\end{array}$ & $\begin{array}{l}\text { No substance } \\
\text { dependence or } \\
\text { substance use (except } \\
\text { for nicotine) within } 12 \\
\text { months }\end{array}$ & $\begin{array}{l}\text { No substance } \\
\text { dependence or } \\
\text { substance use (except } \\
\text { for nicotine) within } 12 \\
\text { months }\end{array}$ & $\begin{array}{l}\text { No substance } \\
\text { dependence or } \\
\text { substance abuse }\end{array}$ & No substance abuse & $\begin{array}{l}\text { No substance } \\
\text { dependence within } 3 \\
\text { months }\end{array}$ & $\begin{array}{l}\text { No substance } \\
\text { dependence (or } \\
\text { abuse) within } 6 \text { (or 3) } \\
\text { months }\end{array}$ \\
\hline
\end{tabular}




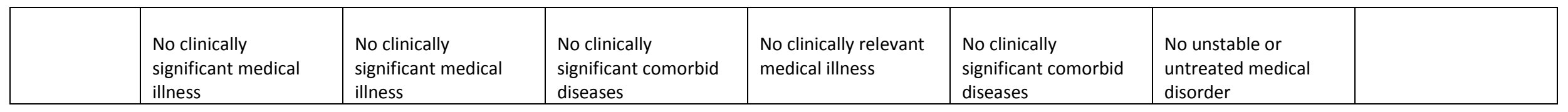

HDRS = Hamilton Depression Rating Scale; MADRS = Montgomery-Åsberg Depression Rating Scale; YMRS = Young Mania Rating Scale 
Table 3. Efficacy/effectiveness measures: SGAs versus placebo

\begin{tabular}{|c|c|c|c|c|c|c|c|}
\hline & \multirow[t]{2}{*}{ Trials } & \multicolumn{2}{|c|}{$\begin{array}{l}\text { Events/total patients } \\
\text { (Event Rate (\%)) }\end{array}$} & \multirow[t]{2}{*}{ RR (95\% Cl) } & \multirow[t]{2}{*}{ NNT $(95 \% \mathrm{Cl})$} & \multirow[t]{2}{*}{$\begin{array}{c}\text { Heterogeneity } \\
Q \text { (p-value) }\end{array}$} & \multirow[t]{2}{*}{$\begin{array}{c}\text { Pooled RR Effect Test } \\
z \text { ( } p \text {-value) }\end{array}$} \\
\hline & & Treatment & Placebo & & & & \\
\hline \multicolumn{8}{|l|}{ Response } \\
\hline Quetiapine 600 & 4 & $526 / 816(64)$ & $269 / 580$ (46) & $1.33(1.19 ; 1.47)$ & $7(5 ; 10)$ & $3.32(0.345)$ & $5.24(<0.001)$ \\
\hline Quetiapine 300 & 5 & $607 / 944$ (64) & $328 / 717$ (46) & $1.36(1.23 ; 1.49)$ & $6(5 ; 9)$ & $4.47(0.347)$ & $6.12(<0.001)$ \\
\hline Olanzapine & 1 & 137/351 (39) & $108 / 355$ (30) & $1.28(1.05 ; 1.57)$ & $12(7 ; 63)$ & & . \\
\hline Aripiprazole & 2 & $148 / 337(44)$ & $147 / 353(42)$ & $1.05(0.88 ; 1.25)$ & NA & $0.30(0.582)$ & $0.57(0.569)$ \\
\hline All SGAs pooled & 12 & $1418 / 2448(58)$ & $852 / 2005(42)$ & $1.3(1.21 ; 1.39)$ & $8(7 ; 10)$ & $14.75(0.194)$ & $7.28(<0.001)$ \\
\hline & & & & & & & \\
\hline Remission & & & & 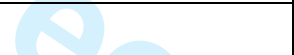 & & & \\
\hline Quetiapine 600 & 4 & $513 / 816$ (63) & $246 / 580$ (42) & $1.39(1.19 ; 1.63)$ & $6(5 ; 9)$ & $6.50(0.090)$ & $4.06(<0.001)$ \\
\hline Quetiapine 300 & 5 & $569 / 944(60)$ & $300 / 717$ (42) & $1.36(1.18 ; 1.57)$ & $7(5 ; 10)$ & $7.97(0.093)$ & $4.26(<0.001)$ \\
\hline Olanzapine & 1 & 115/351 (33) & $87 / 355$ (25) & $1.34(1.06 ; 1.69)$ & $13(7 ; 62)$ & . & . \\
\hline Aripiprazole & 2 & $94 / 337(28)$ & $100 / 353(28)$ & $0.99(0.78 ; 1.25)$ & NA & $0.73(0.393)$ & $-0.11(0.915)$ \\
\hline \multirow[t]{3}{*}{ All SGAs pooled } & 12 & $1291 / 2448(53)$ & $733 / 2005$ (37) & $1.32(1.2 ; 1.45)$ & $9(7 ; 11)$ & $21.15(0.032)$ & $5.83(<0.001)$ \\
\hline & & & & & & 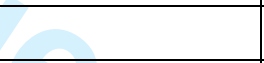 & \\
\hline & & & & & NNH $(95 \% \mathrm{Cl})$ & 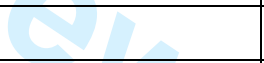 & \\
\hline \multicolumn{8}{|l|}{ Global Dropout } \\
\hline Quetiapine 600 & 4 & $312 / 864(36)$ & 219/608 (36) & $1.05(0.86 ; 1.29)$ & NA & $6.53(0.088)$ & $0.48(0.632)$ \\
\hline Quetiapine 300 & 5 & $333 / 1002(33)$ & $261 / 746$ (35) & $0.98(0.82 ; 1.16)$ & NA & $6.71(0.152)$ & $-0.25(0.806)$ \\
\hline Olanzapine & 1 & $191 / 370(52)$ & $232 / 377$ (62) & $0.84(0.74 ; 0.95)$ & $-11(-36 ;-6)$ & & . \\
\hline Aripiprazole & 2 & $164 / 373(44)$ & $122 / 376(32)$ & $1.35(1.13 ; 1.63)$ & $8(5 ; 21)$ & $0.04(0.846)$ & $3.21(0.001)$ \\
\hline All SGAs pooled & 12 & $1000 / 2609$ (38) & $834 / 2107(40)$ & $1.04(0.92 ; 1.18)$ & NA & $31.96(0.001)$ & 0.60 (0.549) \\
\hline \multicolumn{8}{|c|}{ Inefficacy Dropout } \\
\hline Quetiapine 600 & 4 & $13 / 864(2)$ & $50 / 608(8)$ & $0.23(0.1 ; 0.56)$ & $16(12 ; 25)$ & $5.06(0.168)$ & $-3.27(0.001)$ \\
\hline
\end{tabular}




\begin{tabular}{|l|r|l|l|l|l|l|l|}
\hline Quetiapine 300 & 5 & $23 / 1002(2)$ & $60 / 746(8)$ & $0.3(0.16 ; 0.56)$ & $19(14 ; 30)$ & $5.96(0.202)$ & $-3.71(<0.001)$ \\
\hline Olanzapine & 1 & $73 / 370(20)$ & $121 / 377(32)$ & $0.61(0.48 ; 0.79)$ & $9(6 ; 17)$ &. &. \\
\hline Aripiprazole & 2 & $16 / 373(4)$ & $27 / 376(7)$ & $0.6(0.25 ; 1.42)$ & NA & $1.94(0.163)$ & $-1.16(0.247)$ \\
\hline All SGAs pooled & 12 & $125 / 2609(5)$ & $258 / 2107(12)$ & $0.37(0.25 ; 0.55)$ & $16(13 ; 21)$ & $22.92(0.018)$ & $-4.81(<0.001)$ \\
\hline
\end{tabular}

$\mathrm{RR}=$ relative risk; NNT = number needed to treat; $\mathrm{NNH}=$ number needed to harm; SGAs = second generation antipsychotics 
Table 4. Safety measures: SGAs versus placebo

\begin{tabular}{|c|c|c|c|c|c|c|c|}
\hline & \multirow[t]{2}{*}{ Trials } & \multicolumn{2}{|c|}{$\begin{array}{l}\text { Events/total patients } \\
\text { (Event Rate (\%)) }\end{array}$} & \multirow[t]{2}{*}{$\operatorname{RR}(95 \% \mathrm{Cl})$} & \multirow[t]{2}{*}{ NNH $(95 \% \mathrm{Cl})$} & \multirow[t]{2}{*}{$\begin{array}{c}\text { Heterogeneity } \\
Q \text { (p-value) }\end{array}$} & \multirow[t]{2}{*}{$\begin{array}{c}\text { Pooled RR Effect Tes } \\
z \text { ( } p \text {-value) }\end{array}$} \\
\hline & & Treatment & Placebo & & & & \\
\hline \multicolumn{8}{|c|}{ Adverse Event Dropout } \\
\hline Quetiapine 600 & 4 & $131 / 864(15)$ & $39 / 608(6)$ & $2.36(1.34 ; 4.17)$ & $10(8 ; 16)$ & $7.21(0.066)$ & $2.96(0.003)$ \\
\hline Quetiapine 300 & 5 & $107 / 1002(11)$ & $41 / 746(5)$ & $2.05(1.09 ; 3.86)$ & $19(12 ; 38)$ & $10.84(0.028)$ & $2.22(0.027)$ \\
\hline Olanzapine & 1 & $34 / 370(9)$ & $19 / 377(5)$ & $1.82(1.06 ; 3.14)$ & $24(12 ; 212)$ & . & . \\
\hline Aripiprazole & 2 & $50 / 373(13)$ & $24 / 376(6)$ & $2.1(1.32 ; 3.35)$ & $14(8 ; 35)$ & $0.11(0.744)$ & $3.13(0.002)$ \\
\hline \multirow[t]{2}{*}{ All SGAs pooled } & 12 & $322 / 2609(12)$ & $123 / 2107(6)$ & $2.03(1.53 ; 2.69)$ & $15(12 ; 20)$ & $19.61(0.051)$ & $4.95(<0.001)$ \\
\hline & & & 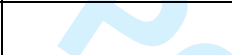 & & & & \\
\hline \multicolumn{8}{|l|}{ Somnolence } \\
\hline Quetiapine 600 & 4 & $184 / 859(21)$ & $38 / 602(6)$ & $3.52(2.24 ; 5.53)$ & $6(5 ; 7)$ & $5.21(0.157)$ & $5.45(<0.001)$ \\
\hline Quetiapine 300 & 5 & $233 / 990(24)$ & $46 / 742(6)$ & $3.91(2.77 ; 5.53)$ & $5(4 ; 6)$ & $5.1(0.277)$ & $7.73(<0.001)$ \\
\hline Olanzapine & 1 & $104 / 370(28)$ & $47 / 377(12)$ & $2.25(1.65 ; 3.08)$ & $6(4 ; 10)$ & . & . \\
\hline Aripiprazole & 2 & $27 / 360(8)$ & $15 / 367(4)$ & $1.83(0.99 ; 3.38)$ & NA & $0.00(0.949)$ & $1.93(0.054)$ \\
\hline \multirow[t]{2}{*}{ All SGAs pooled } & 12 & $548 / 2579(21)$ & $146 / 2088(7)$ & $3.18(2.48 ; 4.08)$ & $6(5 ; 7)$ & $19.2(0.058)$ & $9.11(<0.001)$ \\
\hline & & & & & $\sqrt{20}$ & & \\
\hline \multicolumn{8}{|l|}{ CS Weight gain } \\
\hline Quetiapine 600 & 4 & 69/863 (8) & $15 / 606(2)$ & $3.08(1.77 ; 5.34)$ & $18(13 ; 31)$ & $1.02(0.797)$ & $3.99(<0.001)$ \\
\hline Quetiapine 300 & 5 & $56 / 970(6)$ & $16 / 731(2)$ & $2.37(1.22 ; 4.59)$ & $27(18 ; 58)$ & $5.36(0.253)$ & $2.55(0.011)$ \\
\hline Olanzapine & 1 & $65 / 347(19)$ & $1 / 355(0)$ & $66.5(9.28 ; 476.57)$ & $5(4 ; 6)$ & . & . \\
\hline Aripiprazole & 2 & $17 / 360(5)$ & $12 / 367(3)$ & $1.45(0.7 ; 3.01)$ & NA & $0.57(0.449)$ & $1.00(0.316)$ \\
\hline All SGAs pooled & 12 & $207 / 2540(8)$ & $44 / 2059(2)$ & $2.77(1.72 ; 4.45)$ & $16(13 ; 20)$ & $20.34(0.041)$ & $4.21(<0.001)$ \\
\hline \multicolumn{8}{|c|}{ Treatment Emergent Mania } \\
\hline Quetiapine 600 & 4 & $26 / 863(3)$ & $30 / 606(5)$ & $0.57(0.33 ; 0.98)$ & $-53(-653 ; 26)$ & $2.61(0.455)$ & $-2.02(0.044)$ \\
\hline Quetiapine 300 & 5 & $32 / 997(3)$ & $39 / 746(5)$ & $0.62(0.26 ; 1.47)$ & NA & $10.32(0.035)$ & $-1.09(0.277)$ \\
\hline
\end{tabular}




\begin{tabular}{|c|c|c|c|c|c|c|c|}
\hline Olanzapine & 1 & $19 / 335(6)$ & $23 / 345(7)$ & $0.85(0.47 ; 1.53)$ & NA & . & \\
\hline Aripiprazole & 2 & $11 / 360(3)$ & $6 / 367(2)$ & $1.88(0.7 ; 5.03)$ & NA & $0.01(0.937)$ & $1.26(0.208)$ \\
\hline All SGAs pooled & 12 & $88 / 2555(3)$ & $98 / 2064$ (5) & $0.73(0.48 ; 1.11)$ & NA & $18.45(0.072)$ & $-1.48(0.138)$ \\
\hline \multicolumn{8}{|l|}{ Fatigue } \\
\hline Quetiapine 600 & 3 & $59 / 592(10)$ & $30 / 471(6)$ & $1.65(1.08 ; 2.54)$ & $23(13 ; 113)$ & $0.64(0.726)$ & $2.29(0.022)$ \\
\hline Quetiapine 300 & 4 & $56 / 730(8)$ & $33 / 611$ (5) & $1.44(0.94 ; 2.2)$ & NA & $1.76(0.624)$ & $1.68(0.093)$ \\
\hline Olanzapine & 1 & $36 / 370$ (10) & 12/377 (3) & $3.06(1.62 ; 5.78)$ & $15(9 ; 32)$ & . & . \\
\hline Aripiprazole & 2 & $42 / 360$ (12) & $22 / 367(6)$ & $1.92(1.17 ; 3.15)$ & $17(10 ; 65)$ & $0.65(0.422)$ & $2.58(0.010)$ \\
\hline All SGAs pooled & 10 & $193 / 2052$ (9) & $97 / 1826(5)$ & $1.79(1.41 ; 2.27)$ & $22(16 ; 36)$ & $6.69(0.641)$ & $4.75(<0.001)$ \\
\hline \multicolumn{8}{|l|}{ Sedation } \\
\hline Quetiapine 600 & 4 & $157 / 859$ (18) & $36 / 602(6)$ & $3.5(2.48 ; 4.95)$ & $6(5 ; 8)$ & $2.76(0.43)$ & $7.12(<0.001)$ \\
\hline Quetiapine 300 & 5 & 187/990 (19) & 46/742 (6) & $3.49(2.57 ; 4.74)$ & $6(5 ; 8)$ & $1.74(0.784)$ & $8.02(<0.001)$ \\
\hline Aripiprazole & 2 & $19 / 360(5)$ & $8 / 367(2)$ & $2.42(1.07 ; 5.46)$ & $32(17 ; 289)$ & $0.00(0.946)$ & $2.13(0.033)$ \\
\hline All SGAs pooled & 11 & $363 / 2209$ (16) & $90 / 1711$ (5) & $3.4(2.73 ; 4.24)$ & $7(6 ; 9)$ & $5.23(0.875)$ & $10.9(<0.001)$ \\
\hline & & & & & & & \\
\hline \multicolumn{8}{|l|}{ EPS } \\
\hline Quetiapine 600 & 4 & $77 / 863$ (9) & $29 / 606$ (5) & $1.95(0.95 ; 3.98)$ & NA & $7.7(0.053)$ & $1.83(0.067)$ \\
\hline Quetiapine 300 & 5 & 72/997 (7) & $30 / 746$ (4) & $1.93(0.89 ; 4.16)$ & $\rightarrow$ & $10.85(0.028)$ & $1.68(0.094)$ \\
\hline Aripiprazole & 2 & $115 / 360(32)$ & $37 / 367(10)$ & $3.16(2.25 ; 4.45)$ & $4(3 ; 6)$ & $0.42(0.517)$ & $6.62(<0.001)$ \\
\hline All SGAs pooled & 11 & $264 / 2220(12)$ & $96 / 1719(6)$ & $2.16(1.44 ; 3.23)$ & $14(11 ; 18)$ & $27(0.003)$ & $3.73(<0.001)$ \\
\hline \multicolumn{8}{|l|}{ Akathisia } \\
\hline Quetiapine 600 & 1 & 9/180 (5) & $2 / 180$ (1) & NA & NA & . & . \\
\hline Quetiapine 300 & 1 & 9/179 (5) & $2 / 180(1)$ & NA & NA & . & . \\
\hline Aripiprazole & 2 & $88 / 360(24)$ & $16 / 367(4)$ & $5.59(3.35 ; 9.33)$ & $4(3 ; 6)$ & $0.19(0.666)$ & $6.59(<0.001)$ \\
\hline All SGAs pooled & 4 & 106/719 (15) & $20 / 727(3)$ & $5.37(3.38 ; 8.53)$ & $8(6 ; 10)$ & $0.31(0.958)$ & $7.13(<0.001)$ \\
\hline
\end{tabular}




\section{Page 41 of 44}

Journal of Psychopharmacology

$\mathrm{RR}=$ relative risk; $\mathrm{NNH}=$ number needed to harm; $\mathrm{SGAs}=$ second generation antipsychotics 
Figure 1. MADRS mean change from baseline to endpoint: SGAs versus placebo

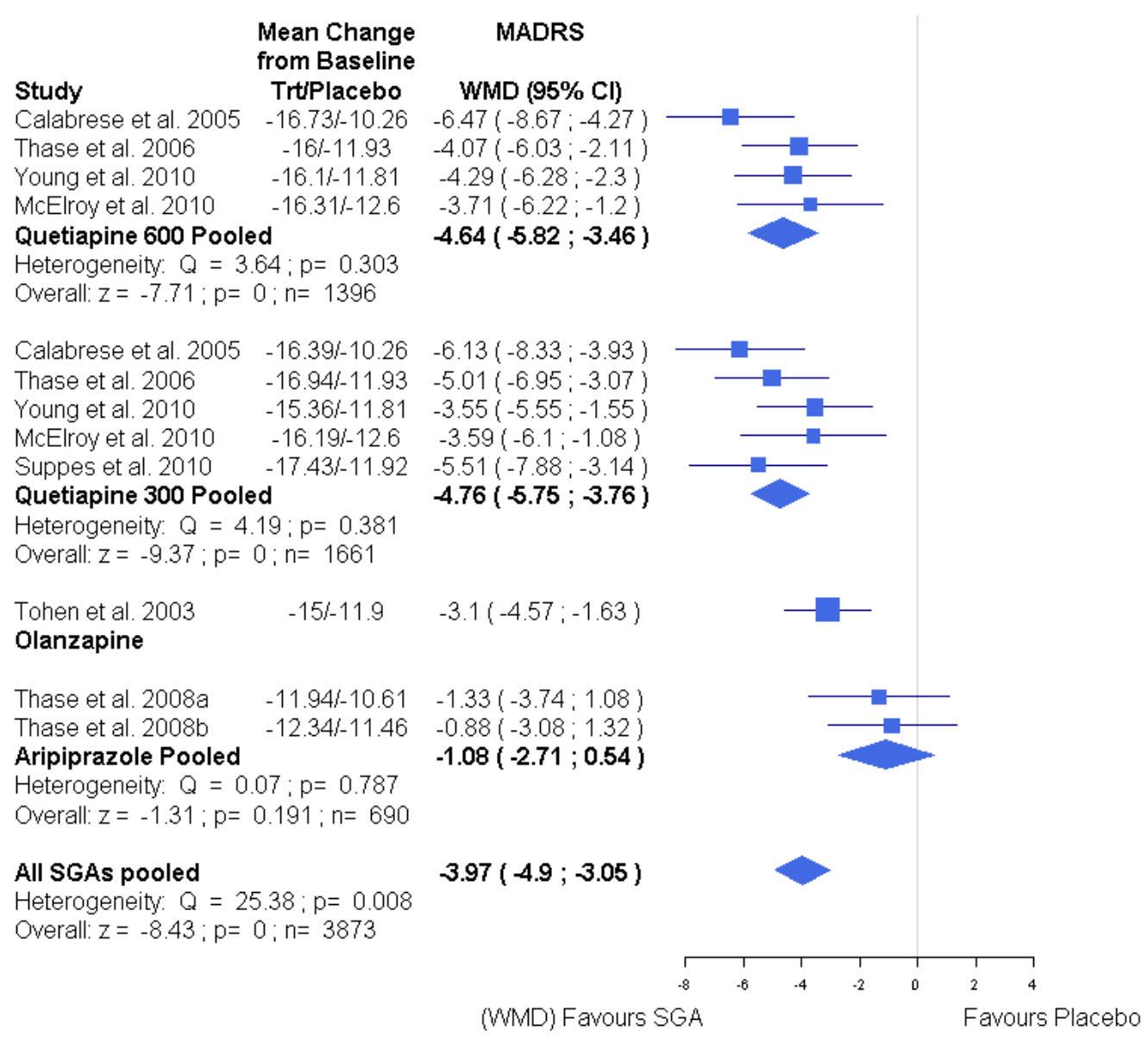

MADRS = Montgomery-Åsberg Depression Rating Scale; $\mathrm{WMD}=$ weighted mean difference 
Figure 2. Weight gain from baseline to endpoint: SGAs versus placebo

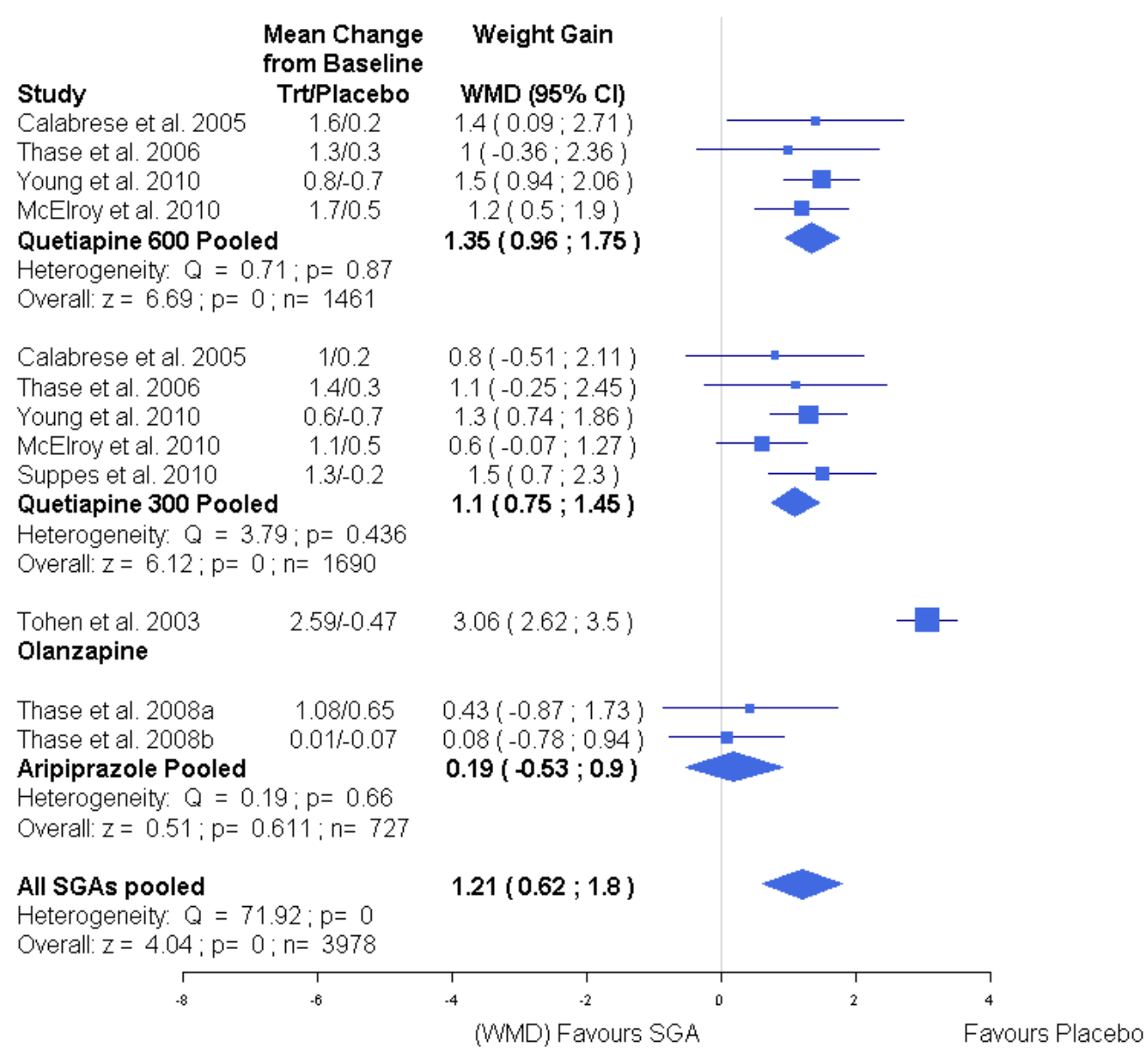

WMD = weighted mean difference 
Jürgen De Fruyt has been a consultant for, received honoraria or scientific/educational grant from, or conducted clinical research supported by the following: AstraZeneca, Boehringer Ingelheim, BristolMyers Squibb, Eli Lilly and Company, GlaxoSmithKline, Janssen-Cilag, Lundbeck, Pfizer, Servier and Wyeth.

Ellen Deschepper has been a consultant for AstraZeneca.

Kurt Audenaert has been a consultant for, received honoraria or scientific/educational grant from, or conducted clinical research supported by the following: AstraZeneca, Eli Lilly and Company, GlaxoSmithKline, Janssen-Cilag, Lundbeck, Pfizer, Servier and Wyeth.

Eric Constant has been a consultant for, received honoraria or scientific/educational grant from, or conducted clinical research supported by the following: AstraZeneca, Boehringer Ingelheim, BristolMyers Squibb, Eli Lilly and Company, GlaxoSmithKline, Janssen-Cilag, Lundbeck, Pfizer, Servier and Wyeth.

Michel Floris has been a consultant for, received honoraria or scientific/educational grant from, or conducted clinical research supported by the following: AstraZeneca, Eli Lilly and Company, JanssenCilag, Lundbeck and Nycomed.

William Pitchot has been a consultant for, received honoraria or scientific/educational grant from, or conducted clinical research supported by the following: AstraZeneca, Bristol-Myers Squibb, Eli Lilly and Company, GlaxoSmithKline, Janssen-Cilag, Lundbeck, Novartis, Pfizer, Servier, Solvay and Wyeth. Pascal Sienaert has been a consultant for, received honoraria or scientific/educational grant from, or conducted clinical research supported by the following: AstraZeneca, Eli-Lilly and Company, GlaxoSmithKline, Janssen-Cilag, Lundbeck, and Servier.

Daniel Souery has been a consultant for, received honoraria or scientific/educational grant from, or conducted clinical research supported by the following: AstraZeneca, Bristol-Myers Squibb, JanssenCilag, Lundbeck, Fonds de la Recherche Scientifique and European Commission.

Stephan Claes has been a consultant for, received honoraria or scientific/educational grant from, or conducted clinical research supported by the following: AstraZeneca, Bristol-Myers Squibb, Eli Lilly 
and Company, Johnson \& Johnson, GlaxoSmithKline and Wyeth. Stephan Claes is a Senior Clinical Investigator of the Fund for Scientific Research - Flanders (FWO - Vlaanderen). 